\title{
STRATEGI PEMASARAN OTAK-OTAK BANDENG (Chanos chanos) (Studi Kasus di Desa Balun Kecamatan Turi Kabupaten Lamongan)
}

\author{
Rohmatul Laili ${ }^{1 *}$, Dona Wahyuning Laily ${ }^{1}$, Fuquh Rahmat Shaleh ${ }^{1}$, \\ Muntalim ${ }^{1}$ \\ ${ }^{1}$ Fakultas Perikanan, Universitas Islam Lamongan \\ *E-mail: rohmahlaili24@gmail.com
}

\begin{abstract}
ABSTRAK
Perkembangan usaha di Kabupaten Lamongan, terutama pada bidang usaha olahan otak-otak bandeng belakangan ini semakin lama semakin berkembang pesat. Keadaan ini menimbulkan persaingan yang rumit antar perusahaan, baik karena pesaing yang semakin bertambah, ataupun volume dan teknologi yang semakin meningkat. Oleh karena itulah perusahaan harus menetapkan strategi pemasaran yang tepat agar mampu bertahan dan berkembang. Tujuan penelitian ini yaitu untuk mengetahui proses pengolahan otak-otak bandeng di Desa Balun Kecamatan Turi Kabupaten Lamongan dan mengetahui strategi pemasaran yang tepat untuk meningkatkan penjualan otak-otak bandeng di Desa Balun Kecamatan Turi Kabupaten Lamongan. Penelitian dilakukan selama 3 bulan dari bulan Maret sampai Mei 2019. Lokasi penelitian dilakukan di Desa Balun Kecamatan Turi Kabupaten Lamongan. Metode yang digunakan pada penelitian ini adalah metode survey deskriptif kuantitatif dengan analisis SWOT, dengan cara mengambil 6 pengusaha yang berada di Desa Balun Kecamatan Turi Kabupaten Lamongan dan masih aktif beroperasi hingga sekarang sebagai responden.

Dari gambar kuadran SWOT hasil penelitian ini menunjukkan bahwa usaha otak-otak bandeng mempunyai posisi yang sangat strategis untuk mendukung perkembangan memperoleh keunggulan strategi, usaha otak-otak bandeng terletak pada kuadran I, artinya pada posisi ini produk suatu usaha sangat mendukung untuk dilakukan strategi pertumbuhan agresif untuk mendapatkan keunggulan perusahaan agar dapat bersaing dengan pengusaha-pengusaha lainnya.
\end{abstract}

Kata kunci: Otak-otak Bandeng, Analisis Strategi Pemasaran, SWOT 


\section{PENDAHULUAN}

Ikan merupakan sumberdaya hayati yang memiliki potensi pengembangan yang besar terutama di Indonesia. Ikan telah menjadi komoditas yang dikenal luas oleh masyarakat dan dimanfaatkan terutama sebagai bahan pangan maupun non-pangan. Ikan memiliki kandungan protein dan asam amino esensial yang dibutuhkan oleh tubuh sehingga ikan merupakan bahan makanan yang bernilai gizi tinggi serta mudah dicerna (Adawyah, 2007). Salah satu potensi perikanan yang cukup besar adalah perikanan tambak. Hasil perikanan tambak yang banyak diminati oleh masyarakat Indonesia dan potensial pengembangannya adalah Ikan Bandeng.

Ikan Bandeng (Chanos chanos) merupakan ikan yang telah dikonsumsi oleh masyarakat Indonesia secara luas serta cukup potensial pengembangannya. Bandeng merupakan jenis ikan budidaya air payau (tambak) yang mempunyai bentuk badan yang memanjang, padat, dapat mencapai ukuran yang cukup besar serta rasanya cukup lezat sehingga membuat bandeng sangat disukai oleh masyarakat Indonesia secara luas. Penyebaran bandeng sangat luas karena ikan ini merupakan ikan yang hidup di daerah payau (estuari) sehingga memiliki toleransi salinitas yang tinggi. Ikan-ikan yang hidup pada daerah estuari memiliki regulasi ion dan air isotonik yang membuatnya dapat hidup di habitatnya (Fujaya, 2004).

Kabupaten Lamongan merupakan salah satu produsen ikan terbesar di Jawa Timur dengan hasil produksi ikan sebesar 116.972,963 ton pada tahun 2014. Ikan Bandeng merupakan komoditas andalan dari sub sektor perikanan. Besarnya produksi bandeng terutama di Kabupaten Lamongan menginspirasi masyarakat Lamongan untuk mengolah Ikan Bandeng dalam bentuk lain (diversifikasi). Ikan tergolong bahan makanan yang mudah sekali busuk oleh sebab itu agar sampai di tangan konsumen masih dalam keadaan baik, diperlukan cara-cara penanganan yang baik pula, salah satunya dengan dijadikan olahan otak-otak bandeng.

Perkembangan usaha di Kabupaten Lamongan, terutama pada bidang usaha pengolahan otak-otak bandeng belakangan ini semakin lama semakin berkembang pesat. Keadaan ini menimbulkan persaingan yang rumit antar pengusaha, baik karena pesaing yang semakin bertambah, ataupun volume dan teknologi yang semakin meningkat. Oleh karena itulah pengusaha harus menetapkan strategi pemasaran yang tepat agar mampu bertahan dan berkembang.

$$
\text { Peran dari lembaga }
$$

pemasaran sangat penting dalam rangka menyampaikan hasil produksi kepada konsumen. Oleh karenanya adalah menjadi keharusan bagi pengusaha penjualan otak-otak bandeng untuk meningkatkan atau membuat strategi yang tepat agar dapat memenuhi sasaran yang efektif. Strategi yang dilakukan harus sesuai dengan keadaan pengusaha. Dimana harus diperhitungkan jumlah dana yang tersedia dengan besarnya manfaat yang diperoleh dari kegiatan strategi yang dijalankan perusahaan.

Disamping itu strategi pemasaran yang diterapkan harus ditinjau dan dikembangkan sesuai 
dengan perkembangan pasar dan lingkungan pasar tersebut. Dengan demikian strategi pemasaran harus dapat memberikan gambaran yang jelas dan terarah tentang apa yang dilakukan pengusaha dalam menggunakan setiap kesempatan atau paduan pada beberapa sasaran pasar.

\section{METODE PENELITIAN}

\subsection{Metode Penelitian}

Metode yang digunakan pada penelitian ini adalah metode survey deskriptif kuantitatif dengan Analisis SWOT, dengan cara mengambil 6 pengusaha yang berada di Desa Balun Kecamatan Turi Kabupaten Lamongan dan masih aktif beroperasi hingga sekarang sebagai responden.

\subsection{Sumber Data}

Sumber data yang digunakan dalam penelitian ini adalah sumber data primer dan sekunder.

a. Data primer

Menurut Sugiyono (2014), menyatakan sumber data primer adalah sumber data yang langsung memberikan data kepada pengumpul data. Sumber primer ini berupa catatan hasil wawancara dan jawaban responden terhadap kuesioner yang dibagikan kepada para karyawan. Data yang merupakan data primer yaitu data produksi, pemasaran, dan lain-lain.

b. Data sekunder

Menurut Sugiyono (2014), menyatakan sumber data sekunder adalah sumber yang tidak langsung memberikan data kepada pengumpul data, misalnya
Berdasarkan latar belakang tersebut, maka peneliti melakukan penelitian dengan judul : "STRATEGI PEMASARAN OTAKOTAK BANDENG (Chanos chanos) (Studi Kasus di Desa Balun Kecamatan Turi Kabupaten Lamongan)."

lewat orang lain atau lewat dokumen. Data ini digunakan untuk mendukung informasi dari data primer yang diperoleh melalui pendapat para ahli, jurnal dan buku. Data yang merupakan data sekunder yaitu letak geografis, keadaan demografi, dan lain-lain.

\subsection{Teknik Pengumpulan Data}

Teknik pengumpulan data merupakan yang paling strategis dalam penelitian, karena tujuan utama dari penelitian adalah mendapatkan data (Sugiyono, 2014). Teknik pengumpulan data yang penulis gunakan dalam penelitian ini adalah sebagai berikut:

1. Penelitian lapangan (Field Research)

Dalam penulisan ini, metode pengumpulan data yang penulis lakukan adalah sebagai berikut:

a. Observasi

Menurut Sugiyono (2014), menyatakan bahwa observasi sebagai teknik pengumpulan data mempunyai ciri yang spesifik bila dibandingkan dengan teknik yang lain, yaitu wawancara dan kuesioner. 
Teknik pengumpulan data dengan observasi digunakan bila, penelitian berkenan dengan perilaku manusia, proses kerja, gejala-gejala alam, dan bila responden yang diamati tidak terlalu besar.

b. Interview/wawancara

Menurut Arikunto (2013), menyatakan bahwa interview adalah sebuah dialog yang dilakukan oleh pewawancara (interviewer) untuk memperoleh informasi dari terwawancara (interviewer).

Menurut $\begin{array}{r}\text { Sugiyono } \\ \text { wawancara }\end{array}$
(2014), digunakan sebagai teknik pengumpulan data apabila peneliti ingin melakukan studi pendahuluan untuk menemukan permasalahan yang harus diteliti, dan juga apabila peneliti ingin mengetahui hal-hal dari responden yang lebih

\section{HASIL DAN PEMBAHASAN}

\subsection{Proses Pengolahan Otak-} otak Bandeng

\subsubsection{Alat yang digunakan untuk} Pengolahan Otak-otak Bandeng

Alat-alat yang digunakan dalam proses pengolahan otak-otak bandeng di Desa Balun Kecamatan Turi Kabupaten Lamongan masih sederhana. Peralatan yang digunakan meliputi:

1. Pisau digunakan untuk memotong ikan

2. Bak digunakan untuk mencuci ikan dan tempat pengulenan bahan-bahan pembuatan otak-otak bandeng mendalam dan jumlah respondennya sedikit/kecil.

c. Angket (Kuesioner)

Dalam penelitian ini metode yang digunakan untuk memperoleh informasi dari reponden adalah berbentuk angket. Angket yang berisi daftar pertanyaan dikirimkan kepada responden untuk diisi.

2. Penelitian kepustakaan (Library Research)

Dalam metode ini penulisan mengumpulkan data dan mempelajari dari buku-buku ataupun bahan-bahan perkuliahan yang berhubungan dengan strategi pemasaran yang nantinya dijadikan sebagai landasan teori.

\subsection{Analisis Data}

Adapun analisis data yang digunakan dalam penelitian ini adalah Matriks Faktor Strategi Internal, Matriks Faktor Strategi Eksternal, Kuadran SWOT, Matriks TOWS atau SWOT.

3. Panci Pengukus digunakan untuk mengukus otak-otak bandeng

4. Wajan digunakan untuk menggoreng bumbu yang sudah dihaluskan

5. Tempeh digunakan untuk mendinginkan otak-otak bandeng setelah dikukus

6. Kompor LPG digunakan untuk mengukus dan penggorengan bumbu

7. Penggilingan digunakan untuk menggiling daging ikan bandeng 
8. Lengser digunakan untuk tempat ikan yang sudah digiling halus

9. Timbangan digunakan untuk menimbang bahan baku ikan bandeng atau bumbu.

\subsubsection{Persiapan Bahan Baku}

Pada tahapan persiapan bahan baku, ikan bandeng yang berasal dari pemasok dipilih oleh pemilik usaha di pasar ikan Lamongan. Ikan yang digunakan untuk pembuatan otakotak bandeng merupakan ikan yang masih segar. Penampakan secara fisik seperti mata bersih serta tidak tenggelam, sisik mengkilap, dan insang masih merah terang.

\begin{abstract}
Bahan-bahan dan bumbu yang digunakan dalam pembuatan otak-otak bandeng antara lain kelapa, telur, minyak goreng, cabe besar, cabe kecil, bawang merah, bawang putih, kemiri, merica pala, jahe, penyedap rasa, garam dan gula pasir. Bahan-bahan tambahan ini diperoleh dari pasar Sidoharjo. Setelah bahan siap, bahan-bahan tersebut lalu dihaluskan untuk pencampuran bumbu ditahap proses selanjutnya.

Proses pengolahan otak-otak bandeng dapat dilihat pada gambar berikut:
\end{abstract}

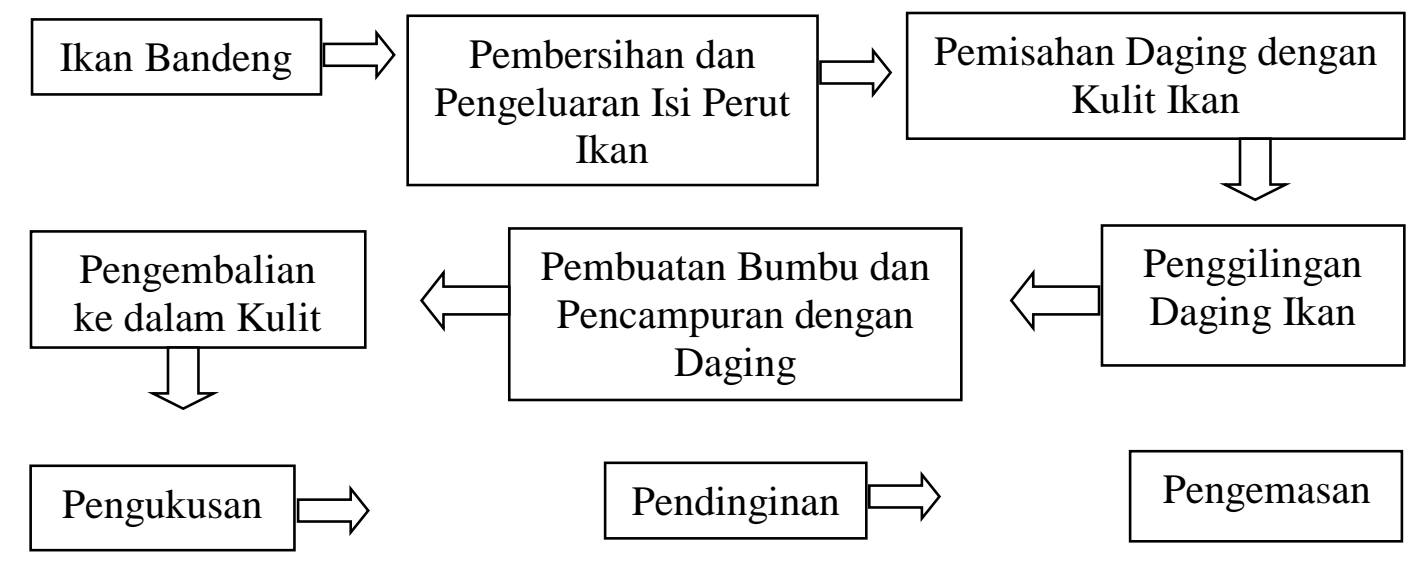

Gambar 1. Proses Pengolahan Otak-otak Bandeng

\subsection{Hasil Analisis Data}

Data yang dijabarkan dalam bab ini tidak hanya didapatkan dari lokasi penelitian saja, tetapi juga berasal dari sumber data yang oleh peneliti dirasa dapat mendukung dan memperkuat keberadaan data utama yang telah didapatkan dari lokasi penelitian.

Dari proses pengumpulan data yang telah dilakukan peneliti pada lokasi penelitian dan dari sumber-sumber lain yang relevan dengan menggunakan metodemetode pengumpulan data yang telah ditentukan sebelumnya didapatkan data-data yang diharapkan dapat menjawab permasalahan penelitian.

Setelah mengetahui kekuatan, kelemahan, peluang dan ancaman pada usaha otak-otak bandeng Desa Balun. Berikutnya akan dianalisa terhadap faktor-faktor tersebut untuk mendapatkan gambaran lebih lanjut, sehingga dapat ditentukan strategi dan langkah-langkah yang tepat untuk diterapkan di masa mendatang.

Langkah awal tahap analisa terhadap faktor-faktor kekuatan, kelemahan, peluang dan ancaman usaha otak-otak bandeng Desa Balun adalah dengan melakukan analisa melalui matrik IFAS (Internal 
Strategic Factor Analisis Summary) dan EFAS (Eksternal Strategic Factor Analisis Summary).

Selanjutnya dari hasil analisa dengan menggunakan matrik IFAS dan EFAS akan dianalisis dengan menggunakan diagram SWOT untuk mendapatkan gambaran akhir kedudukan usaha otak-otak bandeng dengan pengusaha yang sejenis.

\subsection{Matriks Faktor Strategi Internal dan Eksternal}

Tabel 1. Matrik Pembobotan, Rating dan Skor untuk Faktor Internal

\begin{tabular}{|c|c|c|c|c|}
\hline No. & Faktor Internal & Bobot & Rating & Skor \\
\hline A. & \multicolumn{4}{|l|}{ Kekuatan } \\
\hline 1 & Lokasi yang strategis & 0,120 & 3 & 0,36 \\
\hline 2 & Mempunyai alat untuk pengolahan & 0,151 & 4 & 0,60 \\
\hline 3 & Harga relatif murah & 0,145 & 4 & 0,58 \\
\hline 4 & SDM yang berkualitas & 0,101 & 2 & 0,20 \\
\hline 5 & Produk yang sudah familiar di masyarakat & 0,127 & 3 & 0,38 \\
\hline \multicolumn{4}{|c|}{ Jumlah } & 2,12 \\
\hline B. & \multicolumn{4}{|l|}{ Kelemahan } \\
\hline 1 & Kurangnya media untuk pemasaran & 0,076 & 2 & 0,15 \\
\hline 2 & Banyaknya biaya pengeluaran & 0,088 & 3 & 0,26 \\
\hline 3 & Tidak adanya tenaga pemasaran & 0,060 & 2 & 0,12 \\
\hline 4 & Keterbatasan jumlah karyawan & 0,080 & 2 & 0,16 \\
\hline 5 & Kemasan produk kurang menarik & 0,062 & 2 & 0,12 \\
\hline \multicolumn{2}{|r|}{ Jumlah } & & & $\mathbf{0 , 8 1}$ \\
\hline \multicolumn{2}{|r|}{ Total IFAS } & 1,00 & & 2,93 \\
\hline \multicolumn{2}{|r|}{ Selisih IFAS } & & & 1,31 \\
\hline
\end{tabular}


Tabel 2. Matrik Pembobotan, Rating dan Skor untuk Faktor Eksternal

\begin{tabular}{|c|c|c|c|c|}
\hline No. & Faktor Eksternal & Bobot & Rating & Skor \\
\hline A. & \multicolumn{4}{|l|}{ Peluang } \\
\hline 1 & Permintaan pasar yang terus meningkat & 0,128 & 3 & 0,38 \\
\hline 2 & Mendominasi pangsa pasar & 0,095 & 2 & 0,19 \\
\hline 3 & Adanya perluasan pasar & 0,122 & 3 & 0,37 \\
\hline 4 & Berkembangnya teknologi sosial media & 0,135 & 3 & 0,41 \\
\hline 5 & $\begin{array}{l}\text { Banyaknya pembudidaya ikan bandeng di } \\
\text { Lamongan }\end{array}$ & 0,108 & 2 & 0,22 \\
\hline \multicolumn{4}{|c|}{ Jumlah } & $\mathbf{1 , 5 7}$ \\
\hline B. & \multicolumn{4}{|l|}{ Ancaman } \\
\hline 1 & Produk yang Mudah Ditiru & 0,088 & 3 & 0,26 \\
\hline 2 & Banyaknya pesaing & 0,074 & 2 & 0,15 \\
\hline 3 & Munculnya produk baru & 0,081 & 3 & 0,24 \\
\hline 4 & Kesukaan konsumen terhadap produk menurun & 0,081 & 3 & 0,24 \\
\hline 5 & Harga bahan baku cenderung tidak stabil & 0,088 & 3 & 0,26 \\
\hline \multicolumn{2}{|c|}{ Jumlah } & & & $\mathbf{1 , 1 5}$ \\
\hline \multicolumn{2}{|r|}{ Total EFAS } & $\mathbf{1 , 0 0}$ & & 2,72 \\
\hline \multicolumn{2}{|r|}{ Selisih EFAS } & & & $\mathbf{0 , 4 2}$ \\
\hline
\end{tabular}

Dari kedua data tabel di atas bisa dijelaskan bahwa:

1. Jumlah dari skor pembobotan pada kekuatan yaitu 2,12 di atas dari peluang yaitu 1,57 sehingga dapat menciptakan strategi yang menggunakan kekuatan untuk memperoleh peluang. Kekuatan yang ada pada usahanya dapat di manfaatkan secara maksimal agar bisa memperoleh semua peluang yang ada.

2. Jumlah dari skor pembobotan pada kekuatan lebih besar yaitu 2,12 di bandingkan skor pembobotan pada ancaman yaitu 1,15 sehingga dapat menciptakan strategi yang menggunakan kekuatan untuk mengatasi ancaman . Kekuatan yang ada dalam usaha nya dapat di manfaatkan secara maksimal untuk mengantisipasi semua ancaman yang ada dalam usaha tersebut .

3. Jumlah dari skor pembobotan pada kelemahan lebih rendah yaitu 0,81 di bandingkan skor pembobotan pada peluang yaitu 1,57 sehingga dapat menciptakan strategi pada peluang yang mampu meminimalkan kelemahan. Peluang yang ada harus di manfaatkan secara maksimal agar bisa menutupi jumlah kelemahan yang ada pada usaha tersebut.

4. Jumlah dari skor pembobotan pada kelemahan yaitu 0,81, sedangkan skor pembobotan pada ancaman yaitu 1,15 . Sehingga pengusaha harus lebih defensif dalam usahanya untuk meminimalkan jumlah ancaman dan kelemahannya agar usahanya dapat terus maju dan berkembang agar 
mendapatkan lebih banyak keuntungan dan lebih mudah dalam menjual hasil usahanya.

Penjelasan dari tabel di atas dari tahap pengumpulan data, dapat di peroleh lagi yang lebih spesifik dengan cara membuat "Tahap Analisis" ,dimana memanfaatkan Tabel 3. Matriks SWOT semua informasi kedalam model perumusan strategi. Model tersebut adalah Matrik SWOT sehingga dapat memunculkan beberapa kategori yakni strategi SO, strategi ST, strategi WO dan strategi WT dapat di peroleh Matrik SWOT yang dapat di lihat sebagai berikut:

\begin{tabular}{|c|c|c|}
\hline & & \\
\hline EFAS & $\begin{array}{l}\text { - Lokasi yang strategis } \\
\text { - Mempunyai alat untuk } \\
\text { pengolahan } \\
\text { - Harga relatif murah } \\
\text { - SDM yang berkualitas } \\
\text { Produk yang sudah } \\
\text { familiar di masyarakat }\end{array}$ & $\begin{array}{l}\text { - Kurangnya media } \\
\text { untuk pemasaran } \\
\text { - } \text { Banyaknya biaya } \\
\text { pengeluaran } \\
\text { - Tidak adanya tenaga } \\
\text { pemasaran } \\
\text { - Keterbatasan jumlah } \\
\text { karyawan } \\
\text { - Kemasan produk } \\
\text { kurang menarik }\end{array}$ \\
\hline & & \\
\hline $\begin{array}{l}\text { Permintaan pasar yang } \\
\text { terus meningkat } \\
\text { - Mendominasi pangsa } \\
\text { pasar } \\
\text { - Adanya perluasan pasar } \\
\text { Berkembangnya } \\
\text { teknologi sosial media } \\
\text { - Banyaknya } \\
\text { pembudidaya ikan } \\
\text { bandeng di Lamongan }\end{array}$ & $\begin{array}{l}\text { - Meningkatkan kualitas } \\
\text { produk dan pelayanan } \\
\text { agar konsumen merasa } \\
\text { puas dan nyaman } \\
\text { supaya bisa menarik } \\
\text { konsumen baru } \\
\text { Meningkatkan kualitas } \\
\text { produksi dan kualitas } \\
\text { produk } \\
\text { Memperluas promosi } \\
\text { melalui media online } \\
\text { maupun offline }\end{array}$ & 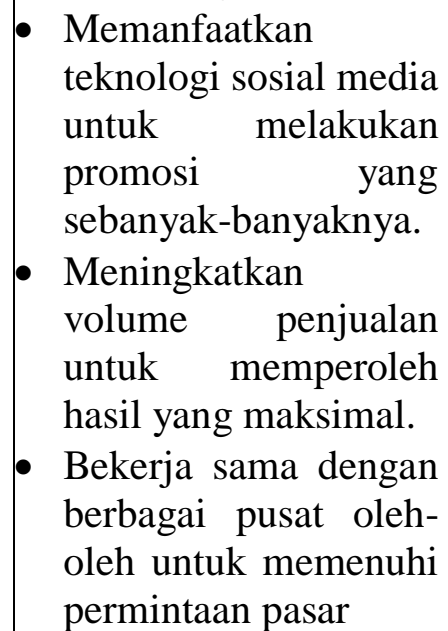 \\
\hline Alicam & & \\
\hline $\begin{array}{l}\text { - Produk yang mudah } \\
\text { ditiru } \\
\text { - Banyaknya pesaing } \\
\text { - Munculnya produk } \\
\text { baru } \\
\text { Kesukaan konsumen } \\
\text { terhadap produk } \\
\text { menurun } \\
\text { - Harga bahan baku } \\
\text { cenderung tidak stabil }\end{array}$ & $\begin{array}{l}\text { - Mengadakan promo } \\
\text { dengan prinsip "harga } \\
\text { murah berkualitas" } \\
\text { untuk meraih } \\
\text { pelanggan } \\
\text { Menjalin komunikasi } \\
\text { yang baik dengan } \\
\text { pelanggan, supaya } \\
\text { pelanggan tidak beralih } \\
\text { ke pengusaha lain }\end{array}$ & $\begin{array}{l}\text { - Memberikan } \\
\text { pelatihan khusus pada } \\
\text { karyawan } \\
\text { - Membuat situs } \\
\text { websiter untuk } \\
\text { memperkenalkan } \\
\text { produk }\end{array}$ \\
\hline
\end{tabular}




\subsection{Kuadran SWOT}

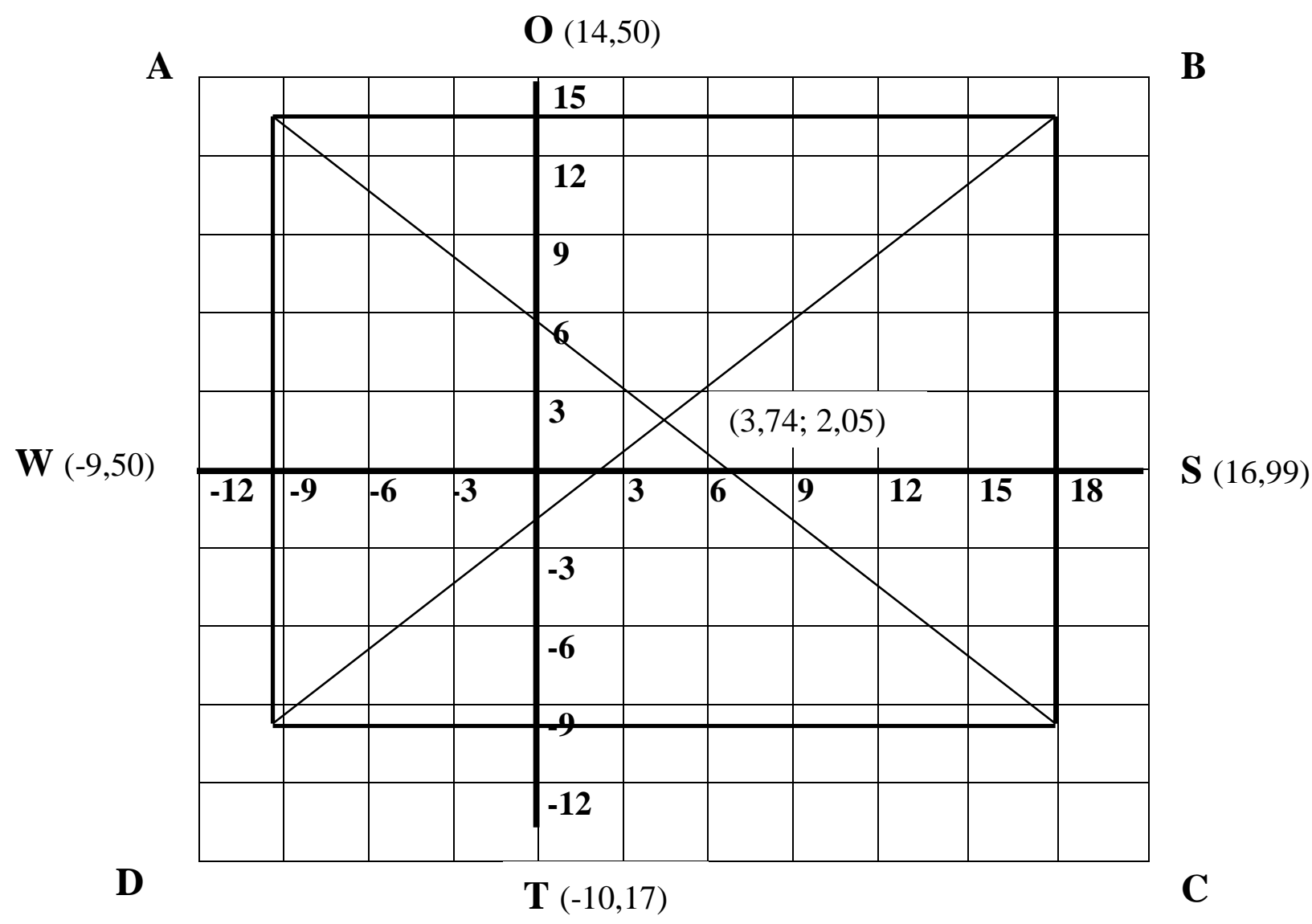

Gambar 2. Kuadran SWOT

Dari gambar disimpulkan bahwa usaha otak-otak bandeng mempunyai posisi yang sangat strategis untuk mendukung perkembangan memperoleh keunggulan strategi, usaha otak-otak bandeng terletak pada kuadran I, artinya pada posisi ini produk suatu usaha sangat mendukung untuk dilakukan strategi pertumbuhan

\section{KESIMPULAN}

Berdasarkan hasil penelitian pada usaha otak-otak bandeng di Desa Balun Kecamatan Turi Kabupaten Lamongan dapat ditarik kesimpulan sebagai berikut:

1. Proses pengolahan otak-otak bandeng dilakukan melalui beberapa tahap yaitu: agresif untuk mendapatkan keunggulan perusahaan agar dapat bersaing dengan pengusahapengusaha lainnya. Strategi agresif merupakan situasi yang sangat menguntungkan. Perusahaan tersebut memiliki peluang dan kekuatan sehingga dapat memanfaatkan peluang yang ada. 
kedalam kulit, pengukusan, pendinginan dan pengemasan.

2. Berdasarkan perhitungan dengan menggunakan analisis SWOT, yaitu IFAS, EFAS dan Matrik SWOT maka usaha otak-otak bandeng mempunyai posisi yang sangat strategis untuk mendukung perkembangan memperoleh keunggulan strategi, usaha otak-otak bandeng terletak pada kuadran I, artinya pada posisi ini produk suatu usaha sangat mendukung untuk dilakukan strategi pertumbuhan agresif untuk mendapatkan keunggulan perusahaan agar dapat bersaing dengan pengusaha-pengusaha

lainnya. Strategi agresif merupakan situasi yang sangat menguntungkan. Perusahaan tersebut memiliki peluang dan kekuatan sehingga dapat

\section{DAFTAR PUSTAKA}

Adawyah, R. 2007. Pengolahan dan Pengawetan Ikan. Jakarta : Bumi Aksara.

Arikunto, S. 2013. Prosedur Penelitian : Suatu Pendekatan Praktik. Cetakan ke-15. Jakarta: Rineka Cipta. memanfaatkan peluang yang ada.

\section{Saran}

Setelah penulis mempelajari keadaan yang terjadi pada usaha otak-otak bandeng di Desa Balun Kecamatan Turi Kabupaten Lamongan, penulis menyarankan kepada pengusaha mengenai beberapa hal yang berkaitan dengan penelitian ini, antara lain sebagai berikut:

1. Meningkatkan kualitas produk dengan cara mengubah kemasan otak-otak bandeng menjadi lebih menarik perhatian dan minat pembeli.

2. Meningkatkan promosi melalui berbagai media internet dan mengikuti eventevent pameran yang diadakan UKM guna mengenalkan produk olahan otak-otak bandeng agar jangkauan pemasaran semakin luas.

Fujaya, Y. 2004. Fisiologi Ikan : Dasar Pengembangan Teknik Perikanan. Rineka Cipta. Jakarta.

Sugiyono. 2014. Metode Penelitian Kuantitatif, Kualitatif, Dan $R \& D . \quad$ Cetakan ke-20. Bandung: Alfabeta. 